\title{
Survey Translation: Why and How Should Researchers and Managers be Engaged?
}

Mandy Sha*, Stephen Immerwahr ${ }^{\dagger}$

Keywords: managing quality, cross-cultural research, multilingual research, survey translation

https://doi.org/10.29115/SP-2018-0016

\section{Survey Practice}

Vol. 11, Issue 2, 2018

\begin{abstract}
This article discusses real-life examples of how researchers and managers can make informed decisions about survey translations, regardless of whether they speak the language of the translation. Collaborating with survey translation experts, researchers and managers can identify points of confusion to facilitate better understanding among all involved, provide guidance to minimize costly and timeconsuming retranslation, and reduce or prevent measurement errors that tend to occur when respondents cannot comprehend the (translated) questions as intended. We also include a case study that illustrates one monolingual Englishspeaking researcher's motivation to become engaged in using and improving translations in surveys.
\end{abstract}

\section{INTRODUCTION}

Translation is a critical tool for researchers and managers to include nonEnglish speakers in survey coverage and estimates. The literature on survey translation to date has been based on the processes and best practices developed for multilingual studies that are cross-national or within a single country like the United States (Behr and Shishido 2016; Forsyth et al. 2007; Goerman and Caspar 2010; J. Harkness 2003; J. A. Harkness and Schoua-Glusberg 1998; J. A. Harkness, Villar, and Edwards 2010; Sha, Park, and Pan 2012; Survey Research Center 2016). However, the literature may seem theoretical to U.S. researchers and managers who have less experience in surveying non-English speakers, who may rely on bilingual colleagues to handle non-English work, and/or who are not fluent in the language(s) in which their surveys are translated and conducted. As the lead author has advocated over the years (Sha 2004, 2005, 2017), we believe that researchers and managers who are not multilingual can effectively manage and influence multilingual research. Using real-life examples and a case study, we address two questions: What are practical ways that U.S. researchers and managers can be engaged in and improve survey translations? Why does it matter and why should they be engaged?

\footnotetext{
* Independent Consultant

† New York City Department of Health and Mental Hygiene
} 
Table 1 Simple reference guide comparing English and Chinese languages for survey translation.

\begin{tabular}{|c|c|c|}
\hline Issues & English & Chinese \\
\hline $\begin{array}{l}\text { ORTHOGRAPHY } \\
\text { (WRITING } \\
\text { SYSTEM) }\end{array}$ & $\begin{array}{l}\text { - Alphabetic spellings, e.g. Chinese } \\
\text { - One set of characters }\end{array}$ & $\begin{array}{l}\text { - Characters, e.g. 中文 } \\
\text { - Character sets: traditional and simplified }\end{array}$ \\
\hline TYPOGRAPHY & $\begin{array}{l}\text { - Boldface, underline, italics, ALL CAPS } \\
\text { - Spacing between words }\end{array}$ & $\begin{array}{l}\text { - Boldface, underline, rarely in italics } \\
\text { - Spacing between characters }\end{array}$ \\
\hline SYMBOLS & $\begin{array}{l}-X \text { (marks a response) } \\
- \text { - (indicates the end of the question text will be } \\
\text { continued in the response categories) (e.g., this house } \\
\text { was -) }\end{array}$ & $\begin{array}{l}\bullet X \text { (indicates negative response) and } \sqrt{ } \\
\text { (indicates affirmative response) } \\
\bullet-\text { (means "one" in Chinese) }\end{array}$ \\
\hline $\begin{array}{l}\text { LINGUISTIC } \\
\text { FEATURES }\end{array}$ & $\begin{array}{l}\text { - In general no distinct dialects } \\
\text { - Auxiliary verbs (e.g., do, be, have) } \\
\text { - Tenses } \\
\text { - Plural forms (e.g., -s, -es) }\end{array}$ & $\begin{array}{l}\text { - Mandarin and Cantonese are major } \\
\text { spoken dialects } \\
\text { - In general, auxiliary verbs, tenses, and } \\
\text { plural forms are not directly applicable }\end{array}$ \\
\hline $\begin{array}{l}\text { SOCIOCULTURAL } \\
\text { CONSIDERATIONS }\end{array}$ & $\begin{array}{l}\text { - Survey conventions are developed in English, such as } \\
\text { the use of symbols. } \\
\text { - Use "you" to address everyone } \\
\text { - Generic terms possible }\end{array}$ & $\begin{array}{l}\text { - English language survey conventions do } \\
\text { not always "translate", e.g. the use of } \\
\text { symbols. } \\
\text { - Term of address “you": 您 (respectful) vs. } \\
\text { 你 (peer-to-peer) } \\
\text { - Context and specific terms needed }\end{array}$ \\
\hline
\end{tabular}

\section{MAKING INFORMED DECISIONS ABOUT CHINESE TRANSLATION}

Table 1 shows a simple reference guide adapted from Sha and Pan (2011) and Sha et al. (2016). It compares English and Chinese orthography, typography, use of symbols, linguistic features, and major sociolinguistic considerations for survey translation. Referring to a guide like this, researchers and managers who are not fluent in the language(s) in which the survey will be implemented can sensitize themselves to issues that might arise in the translation process and make informed decisions with help from survey translation experts.

These are some examples of using the information in Table 1 to make informed decisions about Chinese survey translations:

1. There are two primary written forms of Chinese using "traditional" or "simplified" character sets. By asking themsleves what are the specific Chinese populations to be surveyed (e.g. elderly immigrants? from mainland China? Mandarin or Cantonese speakers?), the researcher or manager can make decisions on the character set in which to produce the Chinese translation, or offer translations in both character sets if the budget allows.

2. When translating an English language mail survey in Chinese, a major implication for managing the translation is acknowledging that English language survey conventions must be adapted for Chinese. For instance, Chinese characters are not alphabetical and cannot be written in lower- or upper-case letters. When specific words are shown in caps for emphasis in the English-language source question, they will require adaptations in the Chinese translation. Figure 1 shows an example from the American Community Survey (ACS) that uses uppercase letters to indicate emphasis in the words FUEL and MOST 
English

Which FUEL is used MOST for heating this house, apartment, or mobile home?

Chinese translation 这所房子、公寓或者移动式房屋中, 最常用来取暖 的燃料是什么?

Figure 1 Emphasis treatment of the same words in English and Chinese translation.

(“American Community Survey Questionnaire" 2018). To deliver similar stimulus, those words were underlined in the Chinese translation ("American Community Survey Language Assistance Guide in Chinese" 2012; Sha, Park, and Pan 2012).

3. For computerized surveys, Chinese translation involving "fills" must be tailored to fit Chinese sentence structure and grammar or the translation will not make sense, like this example provided by Wang et al. (2017):

- English source ("fills" are shown in brackets): Of the people who will be living at [ 4600 Some Street, Apt 101], who [will] rent the house, apartment, or mobile home on [April 1, 2016]?

- Untailored Chinese translation (parallel fills are shown in brackets): 在居住的人当中, [4600 Some Street, Apt 101], 这 所房子, 公寓, 或活动房屋在 [4月1日2016] 谁 [@]租用? (This translation says: Of the people who are living, [4600 Some Street, Apt 101], the house, apartment, or mobile home on [April 1, 2016], who [@] rent?)

To operationalize the Chinese translation in the survey, the fills should be inserted in the grammatically appropriate location in the Chinese sentence; the date should be in the Chinese convention (year, month, day); and the sentence should be restructured to reflect the future time period because the future tense does not directly apply. Without making these adaptations, systems that use the same logic programming for all languages will result in unnatural Chinese translations that use the correct characters and words but cannot be easily understood by the respondents.

\section{MAKING INFORMED DECISIONS ABOUT SPANISH TRANSLATION}

When the researcher or manager is familiar with the type of issues that may arise in the translation process, they can provide guidance before the translation starts. Doing so does not necessarily require language expertise. 
Here are some common challenges and solutions when managing Spanish survey translations, as revealed by a translation expert review conducted by Sha and McAvinchey (2017):

- Use translated words that Spanish speakers in the United States would easily understand. For example, condoms could be translated as preservativos or condones. Use the latter because it is easier to understand.

- Keep reference periods consistent in the survey context. For example, "in the past 12 months" in English is different from durante el uiltimo año (during the past year) because the former may span over 1 calendar year. The translation should match the specific reference period for the survey.

- Use translated questions that have been pretested and recommended in the literature. For example, if the self-rated general health question's response category "fair" were translated in Spanish as satisfactoria, it would be different from the use of Spanish translation regular in established surveys like the Behavioral Risk Factor Surveillance System ("Cuestionario Del BRFSS 2018 (2018 Survey Questions)" 2018) and the National Health Interview Survey ("NHIS Spanish Questionnaire - Family" 2016). Using regular to mean "fair" was also assessed in recent research (Lee and Grant 2009; Schoua-Glusberg and Hinsdale-Shouse 2010).

\section{CASE STUDY: WHY SHOULD RESEARCHERS AND MANAGERS BE ENGAGED IN SURVEY TRANSLATION?}

Stephen Immerwahr is a survey methodologist who oversees the New York City Department of Health and Mental Hygiene's annual telephone-based adult population health survey. An experienced survey researcher, he does not speak a language other than English (monolingual). In Table 2 below, he summarizes why he became engaged in using and improving survey translations from three perspectives: total survey error, public health and health equity, and public administration. Pragmatically, Stephen notes that translations and non-English interviewing may be more cost-efficient than other efforts to reduce sample frame undercoverage, such as including zerobanks (landline exchanges with no listed numbers), refraining from screening out listed businesses, and/or adding non-area cell phone exchanges to local random digit dialing phone surveys. Although bilingual interviewers generally command higher hourly rates, they typically dial numbers already identified as belonging to a household or an individual, so their time can be spent primarily on callbacks and conducting interviews. One argument sometimes heard against including non-English languages is that sample sizes will be too small for separate analysis. While Stephen recognizes the methodological challenges in analyzing small populations, he notes that survey data collection is one 
Table 2 A monolingual researcher's perspective on survey translation goals and impact.

\begin{tabular}{|c|c|c|}
\hline PERSPECTIVE & $\begin{array}{l}\text { GOALS OF SURVEY } \\
\text { TRANSLATION }\end{array}$ & IMPACT EXAMPLES \\
\hline $\begin{array}{l}\text { TOTAL SURVEY } \\
\text { ERROR }\end{array}$ & $\begin{array}{l}\text { Reduce error from sample } \\
\text { frame undercoverage, } \\
\text { particularly in areas with a } \\
\text { large population of non-English } \\
\text { speakers. }\end{array}$ & $\begin{array}{l}\text { Without data collected in Mandarin and Cantonese using Chinese } \\
\text { survey translation, the number of Asian American/Native Hawaiian/ } \\
\text { Pacific Islander adults in NYC's most recent annual health } \\
\text { surveillance survey would have been } 47 \% \text { lower. }\end{array}$ \\
\hline $\begin{array}{l}\text { PUBLIC HEALTH } \\
\text { AND HEALTH } \\
\text { EQUITY }\end{array}$ & $\begin{array}{l}\text { Measure health risk behaviors } \\
\text { and outcomes that may be } \\
\text { different among linguistically } \\
\text { isolated populations. }\end{array}$ & $\begin{array}{l}\text { Allow NYC to evaluate policies, conduct needs assessments, and } \\
\text { create interventions to improve health and reduce health inequities. }\end{array}$ \\
\hline $\begin{array}{l}\text { PUBLIC } \\
\text { ADMINISTRATION }\end{array}$ & $\begin{array}{l}\text { It is the responsibility of local } \\
\text { government to serve all } \\
\text { residents. }\end{array}$ & $\begin{array}{l}\text { Supporting the NYC Department of Health's mission to "protect and } \\
\text { promote the health of all New Yorkers". }\end{array}$ \\
\hline
\end{tabular}

of the only ways to examine emerging issues in these populations and easy to understand translations help to encourage their inclusion in the survey estimates.

Survey translation best practices (Behr and Shishido 2016; J. Harkness 2003; Survey Research Center 2016) recommend a team approach to survey translation that includes subject-matter experts and persons helpful to the process. In this approach, researchers and managers have a key role: They know the study objectives well and the intent behind the questions. Collaborating with survey translation experts, researchers and managers can identify points of confusion to facilitate better understanding among all involved and provide guidance to minimize costly and time-consuming retranslation. When researchers and managers make an informed decision about the inclusion of additional languages and stay engaged in the process of survey translation itself, rather than handing it off to translators to "get it done", they can reduce or prevent measurement errors that tend to occur when respondents cannot comprehend the (translated) questions as intended. This way, researchers and managers can substantially improve the quality of their surveys even when they do not speak all the languages in which the survey is conducted!

\section{ACKNOWLEDGEMENT}

The authors thank Amber Levanon Seligson, Hannah Gould, Shadi Chamany, and Murrey Olmsted for providing review comments of the draft article. This article was drafted while Mandy Sha was senior survey methodologist and business development lead at RTI International. 


\section{REFERENCES}

"American Community Survey Language Assistance Guide in Chinese." 2012. 2012. https://www2.census.gov/programs-surveys/acs/methodology/questionnaires/2012/ LanguageGuide12CHI.pdf.

“American Community Survey Questionnaire.” 2018. https://www2.census.gov/programssurveys/acs/methodology/questionnaires/2018/quest18.pdf.

Behr, D., and K. Shishido. 2016. "The Translation of Measurement Instruments for Cross-Cultural Surveys." In The SAGE Handbook of Survey Methodology, edited by C. Wolf, D. Joye, T.W. Smith, and Y. Fu, 269-87. London, England, Sage.

“Cuestionario Del BRFSS 2018 (2018 Survey Questions).” 2018. 2018. https://www.cdc.gov/ brfss/questionnaires/pdf-ques/2018.

Forsyth, B.H., M.C. Kudela, K. Levin, D. Lawrence, and G.B. Willis. 2007. "Methods for Translating an English-Language Survey Questionnaire on Tobacco Use into Mandarin, Cantonese, Korean, and Vietnamese." Field Methods 19 (3): 264-83.

Goerman, P.L., and R.A. Caspar. 2010. "A Preferred Approach for the Cognitive Testing of Translated Materials: Testing the Source Version as a Basis for Comparison.” International Journal of Social Research Methodology 13 (4): 303-16.

Harkness, J. 2003. “Questionnaire Translation.” In Cross-Cultural Survey Methods, edited by J. Harkness, F.J.R. van de Vijver, and P.P. Mohler. Hoboken, NJ: Wiley.

Harkness, J.A., and A.S. Schoua-Glusberg. 1998. "Questionnaires in Translation.” In CrossCultural Survey Equivalence, edited by J.A. Harkness, 87-126. Mannheim, Germany: ZUMA.

Harkness, J.A., A. Villar, and B. Edwards. 2010. “Translation, Adaptation, and Design.” In Survey Methods in Multinational, Multiregional, and Multicultural Contexts, edited by J.A. Harkness, M. Braun, B. Edwards, T.P. Johnson, L. Lyleberg, P.P. Mohler, B.E. Pennell, and T.W. Smith. Hoboken, NJ: Wiley.

Lee, S., and D. Grant. 2009. "The Effect of Question Order on Self-Rated General Health Status in a Multilingual Survey Context.” American Journal of Epidemiology 169 (12): 1525-30. https://doi.org/10.1093/aje/kwp070.

"NHIS Spanish Questionnaire - Family.” 2016. 2016. https://www.cdc.gov/nchs/nhis/dataquestionnaires-documentation.htm.

Schoua-Glusberg, A., and M. Hinsdale-Shouse. 2010. "How Hispanics Answer the Survey Status Question.” In The American Association for Public Opinion Research Conference. Chicago, IL.

Sha, M. 2004. "Managing Survey Translation: Methodology for Researchers Who Are Not Multilingual." In Presented at the American Association for Public Opinion Research Conference. Phoenix, AZ.

___ - 2005. "Managing Survey Translation: Knowledge Base for Researchers Who May Not Be Multilingual." In Presented at the American Association for Public Opinion Research Conference. Miami, FL.

_- —. 2017. "Managing Quality in Public Opinion Research: Multilingual Questionnaire Pretesting (Even When You Are Not Multilingual).” In Presented at the World Bank, Washington, D.C. 
Sha, M., S. Immerwahr, and M. Sanderson. 2016. "Using the Expert Review Method to Improve a Pre-Existing Survey Translation.” In Presented at the American Association for Public Opinion Research Conference. Austin, TX.

Sha, M., and G. McAvinchey. 2017. "Expert Review of Community Health Survey (CHS) Spanish Instrument Translation.” Report submitted to NYC Department of Health and Mental Hygiene.

Sha, M., and Y. Pan. 2011. "Symbols and Layout: Unique Issues in Chinese Translation of SelfAdministered Survey Forms." In Presented at the American Association for Public Opinion Research Conference. Phoenix, AZ.

Sha, M., H. Park, and Y. Pan. 2012. "Translation Review and Cognitive Testing of American Community Survey (ACS) Language Assistance Guides in Multiple Languages.” Census Burean Working Papers Series.

Survey Research Center. 2016. "Guidelines for Best Practice in Cross-Cultural Surveys." http://www.ccsg.isr.umich.edu/.

Wang, L., M. Sha, and M. Yuan. 2017. "Cultural Fitness in the Usability of U.S. Census Internet Survey in the Chinese Language.” Survey Practice 10 (3): 1-8. 